\title{
SORSANALÍZIS ÉS PSZICHOSZOMATIKA: 5-6 ÉVES ASZTMÁS GYERMEKEK SZEMÉLYISÉGE A SZONDI-TESZT TÜKRÉBEN
}

\section{HARGITAI RITA}

Pécsi Tudományegyetem, Pszichológia Intézet, Személyiség-, Fejlődés- és Klinikai Pszichológiai Tanszék

E-mail: hari@stud.btk.pte.hu

\begin{abstract}
„A betegség az élet sötét oldala, a kinosabbik; a terhesebb állampolgárság. Ugyanis minden ember kettös állampolgársággal születik, egyaránt polgára az egészség és a betegség birodalmának. Bár mindannyian szívesebben használjuk az egészség útlevelét, elóbb-utóbb valamennyien rákényszerülünk, hogy ha rövid idöre is, de átlépjünk a másik királyság állampolgárának szerepébe."
\end{abstract}

Susan Sonntag (1983)

Az utóbbi évtizedben jelentösen megnözekedett az asthma bronchialéban megbetegedók száma. A témaválasztást az indokolja, hogy az asztma a gyermekkor leggyakoribb krónikus megbetegedésévé vált, a vele kapcsolatos mortalitás is fokozatosan emelkedik.

A vizsgálat Szondi sorsanalizisének betegségválasztással kapcsolatos elméletére épül, az ún. morbotropizmus elvére. Szondi szerint a különbözö betegségek megjelenését alapvetöen meghatározza az illetö személy latens öröklött hajlama. A morbotropizmus értelmében a hasonló latens anyaggal - családi tudattalannal - rendelkezö személyek kielégitetlen ösztönfeszültségeiket ugyanazon ösztönkörhöz tartozó betegségforma választásában vezetik le. A vizsgálat során arra kivánok választ kapni, hogy a Szondi által ránk hagyott munkamódszer, a „,kisérleti ösztönészlelés” hozzájárul-e az asztma pszichoszomatikájának megismeréséhez; célom az asztma kialakulásában lényeges szerepet játszó, a családi tudattalan által meghatározott közös ösztönfeszültségek feltárása, az egészséges és az asztmás gyermekekre vonatkozó vizsgálati adatok összevetése mellett.

A vizsgálat során 10 profilos Szondi-tesztet vettem fel 18 asthma bronchialéban szenvedö 5 és 6 éves kor közötti kisgyermekkel. A vizsgálati eredmények elemzésére és értelmezésére az összesített tesztprofilok adatai alapján kerül sor. A Szondi-teszt eredményei jelzik, hogy az asthma brochiale a paroxizmális ösztönkörhöz tartozó betegségforma. Az asztma dinamikáját a rohamok és a közöttük lévö intervallumok adják. Az 5-6 éves egészséges és asztmás kisgyerekek ösztönéletét összehasonlítva pedig minöségi különbséget tapasztalunk.

Kulcsszavak: asthma bronchiale, sorsanalizis, családi tudattalan, morbotropizmus, paroxizmális ventiláció 
$\mathrm{Az}$ asthma bronchiale az egyik legtipikusabb pszichoszomatikus megbetegedés, amelyet már ALEXANDER (1950) a „pszichoszomatikus hétszentség” egyikeként tartott számon. Felvetődik az a kérdés, hogy mit is értünk azon a sokat hallott kifejezésen, hogy asztma? Az asthma bronchiale görög eredetű szó, jelentése: légszomj. E betegséggel kapcsolatos történelmi emlékanyagok számos érdekes hipotézissel kezdődnek: Aretaeus a II. században azt gondolta, hogy az asztmát a tüdőben lévő undorító és viszkózus testnedvek akut kitörése okozza. Hippokratész ziháló, kapkodó légvételt értett rajta, elképzelése szerint a betegség hátterében a légutak hurutja áll. Galénosz azt feltételezte, hogy az agy által kiválasztott anyagok a tüdőbe ömlenek, míg van Helmont az asztmát az epilepszia tüdőbeli ekvivalensének tekintette (BRANYICKY, 1980). Az orvostudomány álláspontja az azóta eltelt több mint 2000 év alatt jelentősen megváltozott: bizonyos időszakokban a morfológiai, máskor a funkcionális szemlélet vált meghatározóvá. Napjainkban az új diagnosztikus eszközök alkalmazása révén a morfológiai szemlélet a domináns. Az asztmának van egy fó gyulladást okozó komponense, amely e betegség operacionalizálható definíciójához is elvezet. 1992-ben Marylandben 18 nemzetközileg elismert szakember közös megegyezése alapján az asztma a légutak krónikus, gyulladásos megbetegedése, amelyben sok sejt játszik szerepet, beleértve a hízósejteket és az eozinofilokat; a fertőzött személyeknél e gyulladást előidéző tünetek - amelyek rendszerint széles körben elterjedt, de változatos formájú obstrukcióval kapcsolódnak össze - spontán módon vagy kezelés hatására gyakran reverzibilisekké válnak, mindehhez okként a különböző ingerekre adott légúti érzékenység fokozódása társul (LENFANT, 1992).

$\mathrm{Az}$ asthma bronchiale olyan szindróma, amelynek etiológiájára vonatkozó ismereteink igen sokrétűek, szerteágazóak. A fenti definíció is utal arra, hogy a túlérzékenység - a hiperreaktivitás - fontos kritériuma az asztmának, azonban önmagában nem elégséges az asztma diagnózisának felállításához. Az asztma genetikai és környezeti meghatározottságára vonatkozóan azonban konszenzus mutatkozik a szakértők körében. Az utóbbi évek kutatási eredményei valószínüsítették, hogy az 5. és a 11. kromoszómával és az egyes HLA locusokkal függnek össze azok a gének, amelyek az asztma öröklődő jellegéért felelősek (CSERHÁTI, 1996), ahol az örökletesség mértékét 59-77\%-ra becsülik (DuFFy és munkatársai, 1990). A fennmaradó hányadot a környezeti tényezők magyarázhatják, amelyek magukba foglalhatják az allergéneket - mint például háziporatka, csótány, pollenek -, a levegőszennyeződést - fotokémiai oxidánsok, kén-dioxid, nehézfémek, ipari szennyeződések -, a cigarettafüstöt és a vírusos fertőzéseket (GERSHWIN, HALPERN, 1994).

Választásom erre a betegségformára irányult, mivel az utóbbi évtizedben jelentôsen megnövekedett az asztmás megbetegedésben szenvedők száma. Az asztma a gyermekkor leggyakoribb krónikus megbetegedésévé vált, mi több, a szakértők szerint (MADARASI, 1996) az asztma prevalenciájára - egy meghatározott időszak alatt az adott populációban lévő asztmás személyek teljes száma - vonatkozó magyar adatok bizonyíthatóan alábecsültek. Az 1. ábra a betegek számának 1990 és 1998 közötti drasztikus növekedését támasztja alá: számuk megduplázódott. 


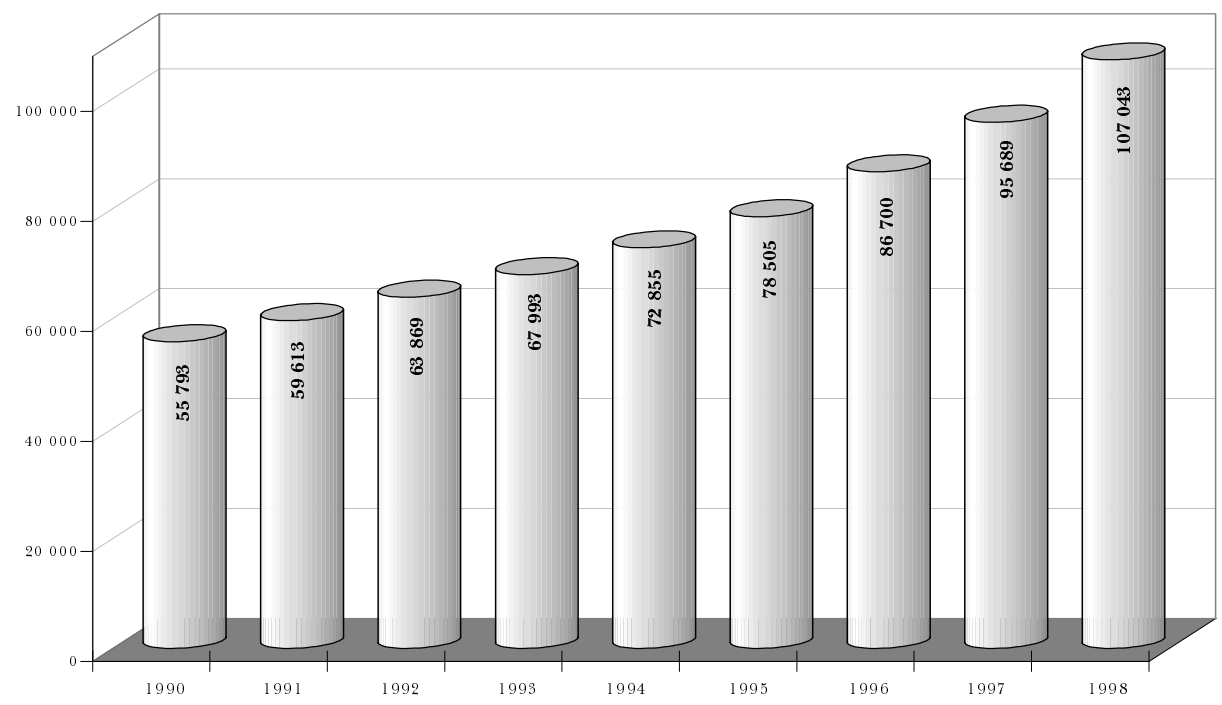

1. ábra. Az asthma bronchialéval nyilvántartott betegek számának alakulása Magyarországon 1990 és 1998 között

(A pulmonológiai intézmények 1999 évi adatai.

Országos Korányi Tbc és Pulmonológiai Intézet, 1999)

Ha pedig az 1975 és 1995 közötti adatokat vesszük figyelembe, a tények még megdöbbentôbbek: az elmúlt 20 évben tizenötszörösére emelkedett az asztmás betegek száma.

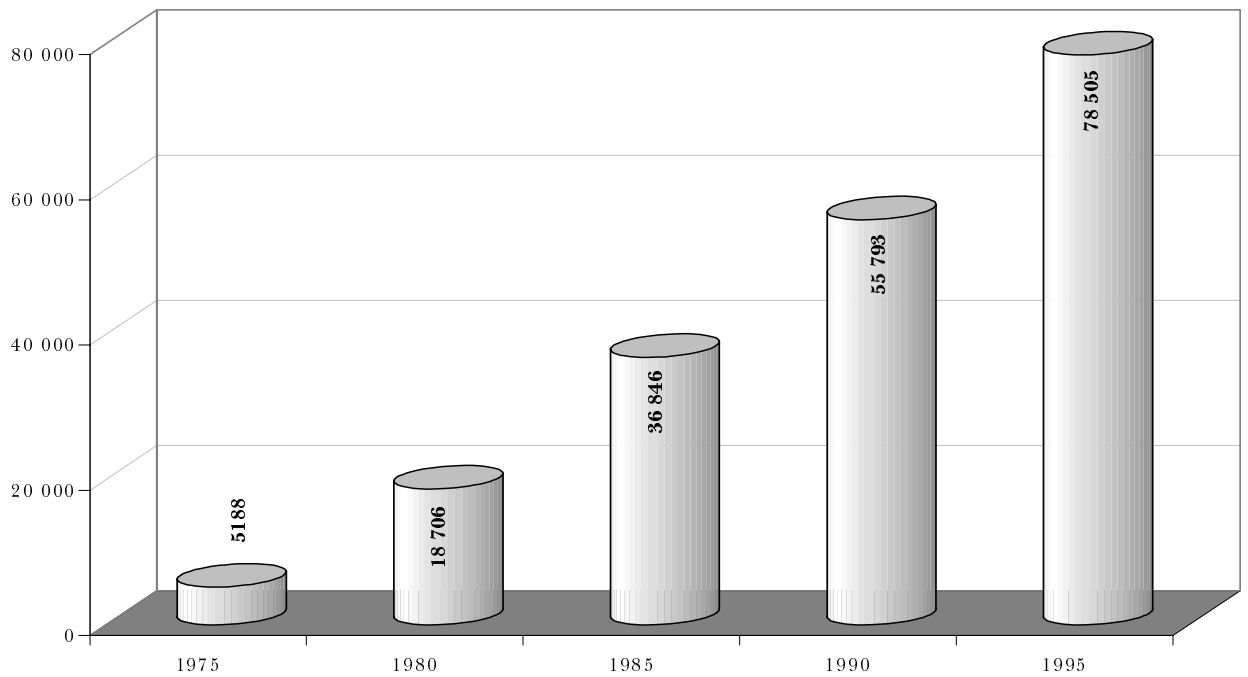

2. ábra. Az asthma bronchialéval nyilvántartott betegek számának alakulása Magyarországon 1975 és 1995 között 
Az asthma bronchiale mortalitása is emelkedő tendenciát mutat, így ez a tény tovább mélyíti a fenti problémát. KOPP (1999) felhívja a figyelmünket arra, hogy míg a századfordulón a fertőző megbetegedések vezették a mortalitási statisztikát, addig az 1990-es évekre a halálokok sorrendje alapvetően módosult: a szív- és keringési megbetegedések szerepelnek az első helyen, ezt a tumoros betegségek követik, míg a balesetek és a krónikus nem fertőző tüdőbetegségek (bronchitis, asztma, tüdőtágulat) képezik a harmadik helyet a sorban. Az asthma bronchialéra vonatkozó magas mortalitási mutató annak ellenére is növekszik, hogy a kifinomultabb diagnosztikai és terápiás eljárások tárháza jelentősen bővült.

\section{SORSANALÍZIS ÉS PSZICHOSZOMATIKA}

A következőkben Szondi Lipót sorsanalízise és a pszichoszomatikus medicina szemlélete közötti találkozási pontokat mutatom be - mintegy hidat teremtve a két tudományterület kapcsolódása mentén. Szondi Lipót ugyan nem dolgozott ki önálló elméletet a pszichoszomatikus megbetegedések - így az asthma bronchiale kialakulására vonatkozóan, munkássága mégis nagymértékben hozzájárulhat a pszichoszomatikus betegségek megértéséhez, ugyanis a pszichoszomatikus medicina alapkövét a bio-pszicho-szociális modell jelenti, amelyet elsőként ENGEL (1977) javasolt. E modell alapja a betegségek biológiai, pszichológiai és szociológiai kölcsönhatásban való szemlélése, ahol ezen említett faktorok mindig együttesen - bár különböző arányokban - játszanak szerepet a betegségek kialakulásában és lefolyásában. Szondi már jóval e bio-pszicho-szociális modell megalkotását megelőzően, a budapesti Gyógypedagógiai Tanárképző Főiskolán működő Magyar Királyi Állami Kórtani és Gyógytani Laboratórium főorvosaként 1927 és 1941 között az értelmi fogyatékos gyermekek „komplex vizsgálatát” tűzte ki célul: növekedésükről, alkati sajátosságaikról, érettségükről, biológiai - immunológiai és allergiás reagálási módjukról, személyiségükről és karakterükről egyaránt készítettek feljegyzést. Mindez azt jelenti, hogy Szondi figyelme egyaránt kiterjedt a fogyatékosság örökléstani, élettani és szociális körülményire. E gondolat jegyében határozta meg Szondi a gyógypedagógia irányultságát is: „A gyógypedagógia nem az elcsökevényesedett képességeket korrigáló pedagógia, hanem sokkal inkább egy egységes, pedagógiai, orvosi, jogi-szociális és vallási-etikai eszközökkel dolgozó tudományág a fogyatékos teljes személyiségének gyógyítására” (SZONDI, 1931).

Később, az 1950-es években szintén hangsúlyozza e három tényező együttes szerepét, bár ő nem így fogalmaz: a biológiai tényezőt úgy határozza meg, mint genetikus örökséget és ösztöntermészetet. Ez annak a talajnak felel meg, amelyet a pszichoszomatikus medicina szervi sérülékenységként, érzékenységként, valamilyen organikus prediszpozícióként tart számon napjainkban. Szondi a szociális - általa környezeti hatásokként említett - tényezőkre is felhívja figyelmünket, amely megfogalmazása szerint: „Az a körülmény, amelybe az ember mint bizonyos szociális rétegbe, társadalmi rendszerbe, illetve rendszertelenségbe (például háború, forradalom, diktatúra) akarva-akaratlanul beleszületik vagy belekényszerül” (SzONDI, 1996a). A szociális rész mellett kiemeli még a mentális tényezők szerepét is, ame- 
lyek az egyéni gondolkodás-, érzékelés-, belátás- és felfogásmódban az illető személy egész lelki-szellemi irányultságaként nyilvánulnak meg.

A fentiekben bemutatott bio-pszicho-szociális modellt - a kapcsolódási pontok között ívelő első hidat - követően a második kerül kifejtésre. Napjainkban már cáfolhatatlan, hogy valamennyi pszichoszomatikus betegség kialakulásában és lefolyásában a gének és a környezet egyaránt szerepet játszanak. Az asthma bronchialéra vonatkozóan is kettős determinációt tételeznek fel, az erre vonatkozó pontos számadatokat a korábbiakban idéztem (lásd DuFFy és munkatársai, 1990). A 3. ábra azt mutatja be, hogy Szondi miként gondolkodik a gének és a környezet által irányított kettős természetről.

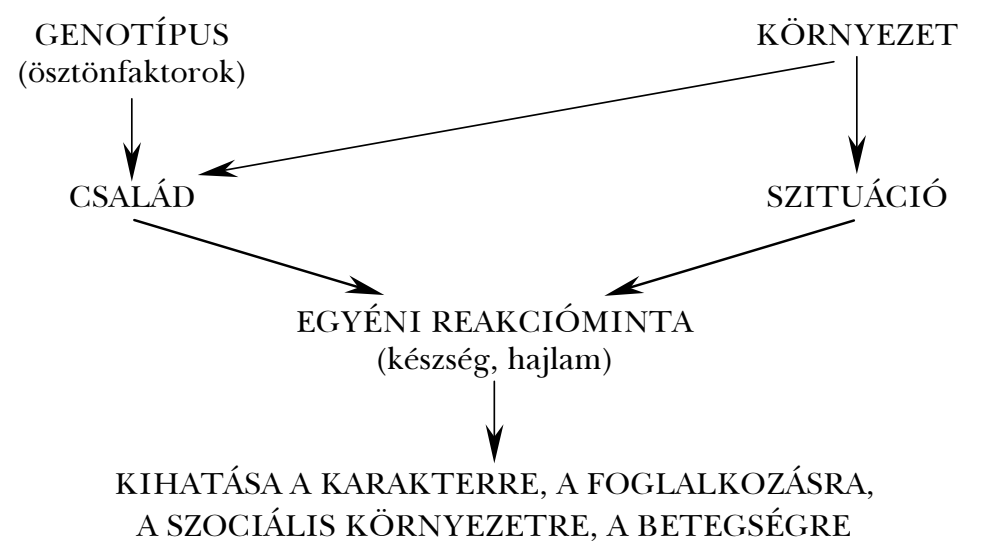

3. ábra. A genetikai örökség és a környezet együttes hatása (BERNER, 1989, 63.)

BERECZKEI (1997, 1999) Szondi Lipótot a „lélek genetikusának” nevezi, hiszen sorsanalízisének fontos tételét jelenti az ösztönök génekre való visszavezetése: „specifikus gének determinálják ösztöncselekedeteinket” (SZONDI, 1996a). Mindez azonban nem jelent merev genetikai determinizmust, hiszen - ahogy a 3. ábra is mutatja - a gének működése nem választható el a környezet hatásaitól: „nem beszélhetünk tehát merev, állandósult, egyvágányú génhatásról. A pszichológiai tünetek nem stabil öröklött jelek, mint például az anyajegy a bőrön. Az úgynevezett kiváltó, exogén faktorokat még akkor sem tagadhatjuk meg, ha nem is magyarázhatunk vele meg mindent" (SzONDI, 1996b). Szondi a Lélektani Laboratóriumban fogyatékos gyermekek - mintegy ezer család tizenötezer tagjának - vizsgálata közben megdöbbentő felismeréshez jutott (SzONDI, 1937): a gének hatásaikat a családi ősökön keresztül, az ún. családi tudattalan révén fejtik ki ránk, bizonyos életutakat megjelenítve, ezáltal megteremtve sorsunk kényszer jellegét. Ez a kényszer azonban nem egyedülálló, hiszen az egyéni szabadság, a választás szintén fontos szerephez jut: mi határozzuk meg, hogy „őseink családi fotóalbumában lapozgató kézként” milyen életutakat követünk, ezt hogyan formáljuk és melyeket 
utasítjuk el. Mindezek alapján „irányítható fatalizmusról” beszélhetünk: „habár az emberi sors előre behatárolt, mégis bizonyos mértékig elöre látható és irányítható”. (SZONDI, 1996a)

A családi tudattalan a választásainkban nyilvánul meg: ez irányítja partner-, barát-, foglalkozás-, betegség- és halálnemválasztásainkat egyaránt. A családi tudattalan múködése révén eljuthatunk a sorsanalízis és a pszichoszomatika közötti kapcsolat harmadik fontos állomásához, a betegségválasztáshoz. Ez a morbotropizmus jelensége, amely - Szondi szóhasználatával élve - arra ad választ, hogy „miért vonzódik valaki ... egy bizonyos betegségformához - és nem máshoz" (SzONDI, 1996b): gyakorlatilag a szimptómaválasztás kérdésével állunk szemben. Szondi felismeri, hogy hasonló családi tudattalannal rendelkező személyek kielégíthetetlen ösztönfeszültségeiket ugyanazon ösztönkörhöz tartozó betegségforma választásában vezetik le. Szondi a betegségválasztás lehetőségeit nem szúkíti le, utalva ezzel arra, hogy választásaink pszichoszomatikus megbetegedési formákra is irányulhatnak.

A fentieken túl Szondi napjaink egészségpszichológiai irányzatának előfutáraként is számon tartható, elérkezve ez által a sorsanalízis és a pszichoszomatika közötti negyedik kapcsolódási ponthoz. Az egészségpszichológia fontos tételét jelenti a korábbi tünet- és betegségközpontú megközelítéssel szemben a személyés egészségközpontú megközelítésre való törekvés: nem a betegségekre kell koncentrálni, hanem az emberre mint önálló entitásra. Pszichológiájában Szondi ugyanezt a szemléletet vallotta: a sorsanalitikust nem az egyedülálló pszichoszomatózis érdekli, hanem a mögötte álló ösztönkör, nem klinikai diagnózist kíván szerkeszteni, hanem az ösztön- és Én-hajlamok arányát kívánja feltárni, amely révén a sorsanalitikus gyógyító eljárás kapujába juthatunk. Szondi Lipót pszichológiai elméletével, terápiás gyógymódjával ,az embert akarta megváltani, tüneteitől, lelki szenvedéseitől, betegségéből kigyógyítani, végső soron egy örömteli léthez, a személyiség kibontakozásához, a szabad sorsválasztás lehetőségéhez kívánta az embert elvezetni" (GYÖNGYÖSINÉ, 1999).

\section{A SORSANALÍZIS ÖSZTÖNRENDSZERE}

A következőkben az aszthma bronchiale hátterében álló közös ösztönfeszültségeket tárom fel, amelyeket a „kisérleti ösztönészlelés”, azaz a Szondi-teszt segítségével ragadhatunk meg. Ezt megelőzően a sorsanalízis ösztönrendszere (SzONDI, 1972) kerül bemutatásra - a vizsgálati eredményekben való eligazodás megkönnyítéséül -, amelyet Szondi az elmebetegségek vonatkozásában dolgozott ki. Ö az elmebetegségeket ösztönmegbetegedéseknek tekinti, ahol a normális és a kóros ösztöntörekvések közötti különbség nem minőségi, hanem mennyiségi jellegű (lásd 1. táblázat). 
1. táblázat. Az elmebetegségek négy önálló ösztönköre

\begin{tabular}{|l|l|l|}
\hline \multicolumn{1}{|c|}{ ÖSZTÖNKÖR } & \multicolumn{1}{|c|}{ VEKTOR } & \multicolumn{1}{|c|}{ FAKTOR } \\
\hline Szexuális ösztönkör & S-vektor / szexuális ösztön & $\begin{array}{l}\text { 1. hermafroditizmus } \\
\text { 2. szadizmus }\end{array}$ \\
\hline Paroxizmális ösztönkör & P-vektor / paroxizmális ösztön & $\begin{array}{l}\text { 3. epilepszia } \\
\text { 4. hisztéria }\end{array}$ \\
\hline Szkizoform ösztönkör & Sch-vektor / énes ösztön & $\begin{array}{l}\text { 5. katatónia } \\
\text { 6. paranoia }\end{array}$ \\
\hline Cirkuláris öröklési kör & C-vektor / kapcsolati ösztön & $\begin{array}{l}\text { 7. depresszió } \\
\text { 8. mánia }\end{array}$ \\
\hline
\end{tabular}

Az 1. táblázat az elmebetegségek Szondi által kidolgozott négy ösztönkörét mutatja. Az ösztönköröket ő vektoroknak nevezte el, utalva ezzel arra, hogy meghatározott ösztönirányt követnek és hátterükben behatárolható mennyiségű ösztönszükséglet áll. A vektorokban jelennek meg az összekapcsolódó ösztönszükségletek. A vektorokon belül két-két ösztöntényezőt ún. faktort különbözethetünk meg, klinikailag és genetikailag egyaránt. Így összességében nyolc speciális ösztönszükségletet kapunk, ezek az ösztönélet gyökerei. S mivel minden ösztöntényezőnek pozitív és negatív változata lehetséges, a nyolc faktor tizenhatféle ösztöntendenciát érvényesít. A tesztológiai jelzéseket használva a következő módon jeleníthetjük meg az emberi fajra jellemzó ösztönköröket (4. ábra):

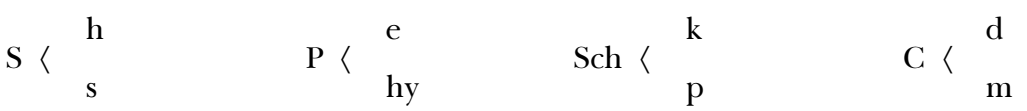

4. ábra. Az emberi fajra jellemző ösztönkörök tesztológiai jelekkel

Az „S” vektorhoz tarozó jelenségek három fő kérdés köré szerveződnek: valamely nemhez tartozás problematikája, a nemi élet ösztönellentétpárja és a nemi tárgyválasztás kérdése köré. Szondi szerint a nemi élet területén a dinamika két ellentétes ösztöntényező által meghatározott. Különbséget tesz a nőies és a férfias ösztönszükséglet között. Az előbbi - a nőies - alkotja a „h” tényezôt, ide tartozik a gyengédség adására és kapására irányuló szükséglet, az odaadás és a szolgálatkészség, az alul maradás és a vezetettség igénye. Az „s” faktort - a férfias ösztönszükségletet - az aktivitás, az erőszak, a támadó kedv, a hódító akarat, az agresszió, a támadás, a vezetés, szélsőséges esetben a szadizmus jellemzi.

A „P”, azaz a paroxizmális ösztön ellentétpárját az „e” és a „hy” faktor adja, amelynek közös jegyei a szükséglet felhalmozódásában, rohamszerű csúcspontjukban és az azt követő hirtelen kiürülésben keresendők. További hasonlóságot jelent, hogy mindkettő a meglepetés erejével hat, azzal a különbséggel, hogy az epilepszia inkább magát a személyt, a hisztéria pedig inkább a környezetet lepi meg. A két tényező ellentétben is áll egymással: az „e” a durva indulatokat, az 
erőszakosságot, a dühöt, a haragot, a gyűlöletet, a bosszút duzzasztja fel, a „hy” pedig a nőies gyengédséget kísérő finomabb érzelmeket, a szeretés- és szerettetésvágyat, a szereplésvágyat.

A harmadik ösztöntengely az „Sch” vektor, az énes ösztön köre. Szondi feltételezése szerint az „én” kialakítója egy ösztön, amely az állatokkal szemben kizárólag az emberre jellemző. A vektoron belül két ösztönszükséglet harca bontakozik ki, az „én”-tágító és az „én”-szűkítő ösztönszükséglet, ahol Szondi szerint az „én”-t eredetileg az egodiasztolés ösztön teremti meg, ez hozza létre az „én”-tudatot mint szükségleti tudatot. Ezzel szemben az egoszisztolés ösztöntényező az állásfoglaló és irányító „én”-t teremti meg, amely dönt a szükségleti tudatba jutott és így tudatossá vált ösztönigények sorsáról.

A „C” vektor a tárgyhoz, az örömforráshoz való kötődés ösztönét mutatja. Bármely ösztönszükségletet csak akkor tudunk kielégíteni, ha először megtaláljuk a - pszichológiai értelemben használt - tárgyat és azt biztosítjuk magunk számára. A tárgyhoz kötődési ösztönnek szintén két tényezőjét különítjük el egymástól: a tárgykeresést és a megtalált tárgyba való kapaszkodást. A kapcsolati tengely szükségleteinek dinamikáját így a valahová tartozás, a hűség, a kapaszkodás, a szerzés ösztöne, másfelől a leválás, a hütlenség és az elmagányosodás adja.

Az ösztönfaktorok nemcsak egymással ellentétesek, de önmagukban is ellentétet hordoznak. Ezt nevezzük interfaktoriális, illetve intravektoriális ellentétnek. Az ellentétekben megjelenő feszültség adja Szondi ösztönelméletének dialektikáját és dinamikáját, a lelki életet nem konstansként, eleve adottként, fatális módon egyedülálló sorsformáiban ragadja meg, hanem az ellentétek harcának dinamikus változásaiban.

Felmerül a kérdés, hogy a bemutatott ösztönrendszer és az arcképekből álló Szondi-teszt között hol van az összekötő láncszem: a megoldást az a kapcsolat jelenti, amely a családi tudattalan által irányított választási magatartás és a pszichés tulajdonságok között van. Szondi genotesztjének alapját - az 1. táblázat alapján korábban már feltárt - nyolc ösztönszükséglet adja, amelyek extrém esetben különböző patológiákhoz vezethetnek. Vajon hogyan lehet megragadni a bennünk lakozó ösztönszükségleteket? Szondi szerint csak a manifeszt ösztönbetegek - azaz az elmebetegek - arcképe rendelkezik olyan felszólító jelleggel, amely segítségével diagnosztizálható az illető személy ösztönélete. A teszt olyan elmebetegek arcáról készült fényképeket tartalmaz, akik betegsége nyilvánvaló a szakember számára és kórtörténetük is ismert. A vizsgált személynek hat arcképsorozatból - bennük nyolc-nyolc képpel - kell kiválasztani azt a két-két fényképet, amelyet rokon- illetve ellenszenvesnek ítél.

\section{A VIZSGÁLAT}

A tanulmány fókuszpontjában álló vizsgálat célja az asthma bronchiale hátterében álló közös ösztönfeszültségek feltárása, amelynek során 10 profilos Szondi-tesztet vettem fel 18 asthma bronchialéban szenvedő kisgyerekkel. Az asthma bronchiale diagnózisát minden gyermeknél már több évvel ezelőtt megállapították. A vizsgálatban részt vevő egyik kislány korábban elhagyta a kórházat, így vele csak 9 profi- 
los teszt készült. A vizsgálat helyszínét a Somogy Megyei Tüdő- és Szívkórház gyermekosztálya adta, ahova a gyerekeket kontrollvizsgálatra rendelték. A kisgyerekek a betegség megállapítása óta folyamatosan orvosi ellenőrzés, illetve gyógyszeres kezelés alatt állnak. A teszt felvételének időpontjában valamennyi kisgyerek már betöltötte az ötödik életévét, de a hatodikat még nem. A vizsgálatban részt vevő két kisfiú mentális színvonala - annak ellenére, hogy már betöltötték az ötödik életévüket - nem tette lehetővé az adekvát választásokat: az egyik vizsgálati személy a szélen lévő elemeket preferálta, a másikuk szisztematikusan balról jobbra haladt. Az ő választásaik nem tekinthetők adekvátnak, így eredményeik nem kerültek feldolgozásra. A fiúk és a lányok aránya $10: 6$ volt, ami megfelel az ilyen idős asztmás kisgyerekek átlagos nemi megoszlásának.

A vizsgálati eredmények bemutatására majd értelmezésére a 16 kisgyerek 10 profilos tesztjének összesített adatai alapján kerül sor. Legelőször a vektorreakciók gyakorisági értékeit tüntettem fel. E táblázatba gyüjtött adatokból kitűnik, hogy a különböző vektorok szempontjából melyek azok a választott reakciók, melyek leginkább jellemzőek a vizsgált személyekre (lásd 2. táblázat).

2. táblázat. A vektorreakciók gyakorisági értékei

\begin{tabular}{lrrrr} 
& S & P & Sch & C \\
\hline++ & 45 & 6 & 4 & 15 \\
+- & 12 & 17 & 8 & 24 \\
+0 & 15 & 6 & 4 & 8 \\
+ \pm & 10 & 6 & 2 & 9 \\
-+ & 8 & 11 & 15 & 9 \\
-- & 7 & 29 & 26 & 6 \\
-0 & 6 & 19 & 23 & 11 \\
- \pm & 4 & 6 & 7 & 5 \\
$0+$ & 9 & 2 & 5 & 26 \\
$0-$ & 12 & 18 & 20 & 14 \\
00 & 7 & 9 & 13 & 9 \\
$0 \pm$ & 2 & 5 & 9 & 8 \\
\pm+ & 9 & 5 & 5 & 4 \\
\pm- & 6 & 12 & 8 & 3 \\
\pm 0 & 5 & 7 & 6 & 7 \\
\pm \pm & 2 & 1 & 4 & 1 \\
össz: & 159 & 159 & 159 & 159
\end{tabular}

A kapott eredmények értelmezését megkönnyíti, ha ezen reakciótípusokat összevetjük Szondi vizsgálati eredményeivel: az 5-6 éves egészséges gyerekekre leginkább jellemzô profillal (3-4. táblázat). 
3. táblázat. Az 5-6 éves korú egészséges gyerekekre jellemző ösztönprofil (A svájci Szondi Intézet szemináriumi anyaga alapján)

\begin{tabular}{|c|c|c|c|}
\hline $\mathrm{S}$ & $\mathrm{P}$ & Sch & $\mathrm{C}$ \\
\hline++ & -- & -- & +- \\
\hline+0 & $0-$ & \pm- & $0-$ \\
\hline+- & -0 & $\begin{array}{l}+- \\
-0\end{array}$ & $\begin{array}{l}+0 \\
+ \pm\end{array}$ \\
\hline
\end{tabular}

4. táblázat. Az 5-6 éves asztmás gyerekekre jellemző csoportos ösztönprofil

\begin{tabular}{cccc} 
S & P & Sch & C \\
\hline++ & -- & -- & 0 + \\
& $-\mathbf{0}$ & $-\mathbf{0}$ & +- \\
& $\mathbf{0}-$ & $\mathbf{0 -}$ &
\end{tabular}

A táblázat melletti nyíl jelzi, hogy felülről lefelé csökken a gyakoriság, de mindegyik alapvetően gyakorinak számít. (Az eredmények értelmezésénél a két csoport ösztönprofiljának különbségeire helyezem a hangsúlyt, amit a 4.táblázatban a vastagon szedett kiemelés jelez.) A vizsgálati személyek szexuális tengelyét szintén az egészséges szexualitás $(S++)$ jellemzi leginkább, viszont a telített reakciók magas értéke jelzi a problematikus agressziókezelést: felduzzadnak a rombolás erői, jellemző az agresszió levezetésének nehézsége. A paroxizmális tengely reakciói már változatosabbak: a vizsgált személyek gyakran mutatnak belső pánikra, szorongásra utaló jegyeket ( $\mathrm{P}--)$ - ebben megegyezést mutatnak az egészséges csoport ösztönprofiljával. Az asztmás gyerekeknél azonban fokozottabban jelentkezik a lágy érzelmek elrejtésének igénye, ezáltal az érzelmi élet megdermedése $\left(\right.$ hy $^{-1}$ ). Az asztmás gyerekeknél kiemelkedő jelentősége van a $\mathrm{P}-0$ reakciónak is: a harag, gyưlölet, bosszú, irigység és féltékenység morális fékek nélküli felhalmozódása. A telített reakciók megjelenése pedig a kitörés veszélyét is jelzik. Az énes ösztön tekintetében is jelentős különbségek tárhatók fel az egészséges gyerekekhez viszonyítva: az énes vektorban az alkalmazkodó, lemondó személyiségtípus fordul elő a legnagyobb arányban, majd ezt követi az ösztöntörekvések letiltása és a p-faktor kiürítése. Ezeken kívül jelentős mértékben figyelhető meg a totális projekció, azaz a participáció, amely az énfejlődés legkorábbi szakaszához, a duálúnióhoz kapcsolódik. Ez egy olyan projekció, amely sohasem tudatosul, és teljesen nélkülözi az állásfoglalást.

Az általam vizsgált személyek és Szondi adatai közötti legjelentősebb különbségeket a kapcsolati tengely mutatja: korábban a leggyakoribb vektorreakciók tekintetében mindig egyezést találtunk, most azonban más a profil. A keresés klasszikus 
képe $(\mathrm{C}+-)$ helyett elsődlegesen az egészséges kapcsolat $(\mathrm{C} 0+!)$ jelenik meg tesztológiailag. E látszólag idilli kép ellen szól azonban az, hogy a vizsgálati személyeknél fokozottabban jelentkezik a kapaszkodás (telített reakciók formájában), így ez szorongást keltő állapottá válik.

A soron következő, 5. táblázat a 16 féle ösztöntörekvést mutatja, a hozzá tartozó választási gyakoriságokkal, balról jobbra csökkenő tendenciát mutatva. A második sor a telített reakciók számára vonatkozik. Az összehasonlítás tájékoztat a legerősebb átütőerőt képviselő ösztöntörekvésekrőll, illetve az ezekbőll adódó ösztönvészről.

5. táblázat. A választott ösztöntendenciák mennyiségi összehasonlítása

\begin{tabular}{rrrrrrrrrrrrrrrr}
$\mathrm{h}+$ & $\mathrm{hy}-$ & $\mathrm{k}-$ & $\mathrm{s}+$ & $\mathrm{e}-$ & $\mathrm{p}-$ & $\mathrm{d}+$ & $\mathrm{m}+$ & $\mathrm{m}-$ & $\mathrm{s}-$ & $\mathrm{e}+$ & $\mathrm{d}-$ & $\mathrm{p}+$ & $\mathrm{h}-$ & $\mathrm{hy}+$ & $\mathrm{k}+$ \\
\hline 83 & 76 & 71 & 71 & 65 & 62 & 57 & 53 & 47 & 37 & 35 & 31 & 30 & 25 & 24 & 18 \\
147 & 19 & 9 & 28 & 10 & 4 & 4 & 24 & 13 & 6 & 2 & 1 & 3 & 3 & 4 & 0
\end{tabular}

Legnagyobb intenzitással a szeretet és a gyengédség iránti igény hat $\left(\mathrm{h}^{+}\right)$. A telített reakciók 50\%-nál nagyobb mértéke jelzi, hogy kielégíthetetlen szükségletről van szó, így libidófelhalmozás jön létre. Jelentős erővel hat a lágy érzelmek elrejtésének, elfojtásának igénye, a szorongás, az introverzió (hy-). A hy ${ }^{-}$, a k $\mathrm{k}^{-}$, a $\mathrm{p}^{-}$együttesen a szomatizáció képét adják. Azonban a szomatizáció nem önmagában jelenik meg, hanem összekapcsolódik az $\mathrm{e}^{-}$igényével is. Az $\mathrm{e}^{-}$hy ${ }^{-}$konstelláció a szorongásnak, a pániknak felel meg, így elmondható, hogy az 5-6 éves asztmás gyerekeknél a szorongás a szomatizáció kísérőszindrómájaként fontos szerepet játszik. A szél-közép dialektikájára vonatkozó elemzés révén feltárható, hogy a közép önmagában sohasem vezet szomatizációhoz. A legintenzívebben ható ösztöntörekvések széliek: a $\mathrm{h}^{+}$és $\mathrm{s}^{+}$. A telített reakciók arányának magas volta jelzi, hogy kielégíthetetlen szükségletekről van szó: a kielégülésre képtelen gyengédség- és szeretigényről. Fontos az agresszió levezetésének lehetetlensége is: a vizsgált személyek agresszív késztetéseiket eltitkolják $\left(\mathrm{s}^{+1} \mathrm{hy}^{-1}\right)$, destruktív agressziójukat - a motórium által - nem a külvilág felé vezetik le, hanem az én ezen ösztönigényt a test felé tereli. Az eredmény: egy meghatározott szervterület hibás beidegzése, jelen esetben a légzőszervrendszeré.

A fentieken túl kiemelkedő az $\mathrm{m}+$ tendencia jelentősége. Igaz ugyan, hogy nem a legjelentősebb átütőerővel hat, de a telített reakciók aránya igen magas (45\%). Mindez megerôsíti a vektorreakcióknál már korábban leírtakat, mely szerint az asztmás gyerekek anyában való megkapaszkodása frusztrált; a tesztológai jelek az elhagyott, de leválásra képtelen gyermek állapotát jelenítik meg.

A gyakorisági értékeket felhasználva meghatározhatjuk az 5-6 éves asztmás gyerekekre jellemzö ösztönképletet, ahol a megosztott és nulla reakciókat egy emeletes tört formájában jelenítjük meg (lásd 5. ábra). 
Szimptomatikus faktorok:
Szubmanifeszt, illetve szublatens faktorok:
Gyökérfaktorok:

5. ábra. Az 5-6 éves asztmás gyerekekre jellemző́ csoportos ösztönképlet

Szondi terminológiáját használva azokat a faktorokat nevezzük gyökérnek, amelyek - mennyiségi túlsúlyuk miatt - aktuálisan nem elégülhetnek ki, így a tudattalan dinamikája révén megbetegítő hatást gyakorolhatnak. A vizsgált személyek esetében a gyökérfaktorok $\left(\mathrm{h}^{+}, \mathrm{s}^{+}\right)$a kielégülésre képtelen személyszeretet és gyengédség iránti igényt mutatják, amelyhez az agresszió levezetésének, kiürülésének problémája társul. A gyökérfaktorok feletti szint $\mathrm{m}^{+}$tendenciája is megbetegítő faktorként értelmezhető: az anyában való megkapaszkodás frusztrációjaként. E frusztrációt az állásfoglalás feladása kíséri $\left(\mathrm{k}^{0}, \mathrm{p}^{0}\right)$. Ezen kielégíthetetlen ösztöntendenciákból származó feszültséggel szemben az általam vizsgált asztmás gyerekek a teszt felvételének időszakában keresési csenddel $\left(\mathrm{d}^{0}\right)$ védekeznek. A szubmanifeszt, illetve szublatens szinten lévő ösztöntendenciák segítségével a vizsgált személyek jövőbeli viselkedését prognosztizálhatjuk: mind a két paroxizmális vektorhoz tartozó ösztönigény (e, hy) itt helyezkedik el, így a forgószínpadszerü dinamikából kifolyólag a feszültség paroxizmális roham formájában való levezetődése várható.

$\mathrm{Az}$ asztmás gyermekekre jellemző latenciasort - a vektorok interfaktoriális feszültsége alapján történő besorolást - mutatja a 6. ábra. A latenciasort csoportra vonatozóan G. PETZ (1953) eljárása alapján készítettük el.

$$
\frac{\mathrm{C} \mathrm{m}^{+}}{0,75}: \frac{\mathrm{SCH} \mathrm{p}}{0,22}: \frac{\mathrm{S}}{0}: \frac{\mathrm{P}}{0}
$$

6. ábra. Az asztmás gyermekekre jellemzó csoportos latenciasor

A latenciasor a mindenáron való kapaszkodás és a kielégületlen elfogadás iránti igény $\left(\mathrm{Cm}^{+}\right)$ösztöneredetű problémáját mutatja. Mindehhez a participáció $\left(\mathrm{SCHp}^{-}\right)$ problematikája is társul: az anyával való egyesülés vágya. Ez az énfejlődés legkorábbi szakaszára, az anya és a gyermek egységére, a duálúnióra való visszavágyódás igényét jelzi. A vizsgálati személyek ezen ösztönveszély elhárítására paroxizmális ventilációt $(\mathrm{P})$ használnak: érzelmi kiürítéssel, jelen esetben asztmás roham formájában csökkentik a veszélyt. Szelepként - feszültséglevezetést képviselő lehetőségként - nemcsak a paroxizmális, de az agresszív természet $(\mathrm{S})$ is megjelenik. Az asztmás kisgyerekek az agresszív tendenciáikat saját maguk ellen fordítják, ezáltal büntetik önmagukat. A latenciasor szelepként megjelenő két tagja (P, S) egyértelműen jelzi az önmaga ellen fordított agresszió és a szomatizáció kapcsolatát.

$\mathrm{Az}$ általam vizsgált asztmás gyermekek a teszt felvételének ideje alatt a $\mathrm{Cm}^{+}$ ösztönosztályhoz tartoznak: az ösztönélet dinamikáját a tárgyba való belekapasz- 
kodás szükséglete határozza meg, ahol a tárgy jelen esetben az anya. Az anyában való megkapaszkodás szükséglete irreális, így soha nem elégülhet ki. Bizonytalanok a tárgy birtoklásában, emiatt folyamatosan szoronganak annak elvesztésétől. Alapvető az elfogadás iránti igényük is, amely azonban szintén kielégíthetetlen, emiatt pedig participációs zavarokra hajlamosak. Ezzel szemben Szondi vizsgálati eredményei szerint az 5-6 éves egészséges kisgyerekek az $\mathrm{S} \mathrm{h}^{+}$ösztönosztályhoz tartoznak (SzONDI, 1973). Ez azt mutatja, hogy az asztmás kisgyerekek egészséges társainál egy sajátos ösztönfolyamat zajlik: náluk már megindult az anyáról való leválás folyamata, melyet az östárgy elveszitésének nevezhetünk. Az őstárgy elveszítése miatt magányossá válnak a gyerekek, ezt nehezen tudják elviselni, így keresésre indulnak. E keresés célja új tárgy találása, amely révén többé-kevésbé pótolható az anyai gyengédség. 5-6 éves - az Ödipális kort elhagyó - életszakaszban ez tekinthetô az ösztönélet adekvát dinamikájának.

\section{AZ AGRESSZIÓ SZEREPE}

Az asztmás gyerekek ösztönéleti dinamikájának leírásában a továbbiakban az agresszió szerepét emelem ki. Szondi az agresszió genotesztben való megjelenésének négy - a vektorokhoz kötődő - formáját írta le (GYÖNGYÖSINÉ, 2000), amelyek a következők: legmarkánsabban a szexuális ösztönkörön belül megjelenő „s” - szadizmus - ösztönigény tájékoztat az agresszív késztetésekről. A paroxizmális ösztönkörben leírta a káinizmust, amely a gyilkos, káini indulatok és a mindent jóvá tenni akarás hátterében lévő indulati agressziót jelzi $\left(\mathrm{e}^{-}\right)$. Az énes ösztönkörben szintén kapunk utalást az agresszióra: az ént tagadó, az ént és a külvilágot szétromboló destruktív agresszió $\left(\mathrm{k}^{-}\right)$formulája. A cirkuláris ösztönkörön belül kapcsolati frusztrációból származó agressziót azonosította Szondi, amely a túl erős kapaszkodás $\left(\mathrm{m}^{+}\right)$, illetve a mindenről való leválás $\left(\mathrm{m}^{-}\right)$igényében mutatkozik meg. A túl erős kapaszkodás és az agresszió összefüggéseit Szondit megelőzően Hermann Imre írta le: „a mindenképpen való megfogózni, belekapaszkodni akarás könnyűszerrel csap át agresszív viselkedésbe" (HERMANN, 1984), ezáltal válhat a megkapaszkodás a szadisztikus libidó forrásává.

Az 5-6 éves asztmás gyermekek teszteredményeit áttekintve az agresszió jegyeinek vonatkozásában az alábbiak állapíthatók meg. A vizsgálati személyek szexuális tengelyének reakciói - a telített reakciók magas értéke alapján - jelzik az agreszsziókezelés problematikáját: felduzzadnak a rombolás erői, jellemző az agresszió levezetésének nehézsége. Az asztmás gyerekeknél kiemelkedő jelentősége van a $\mathrm{P}$ -0 reakciónak, amely a durva, káini indulatok - harag, gyúlölet, bosszú, irigység, féltékenység - morális fékek nélküli felerősödését mutatja. Ezekben az esetekben a személy agresszív késztetéseit önmaga ellen fordítja, „saját agyának, szívének, végtagjainak keringésére irányítja, ily módon olyan »rohamban szenvedő«, »homo paroxizmálissá « teszi magát, aki nem ellenségét veri kékre-zöldre, hanem saját bőre válik »kiütésessé«, nyelve dadogásig görcsössé” (SZONDI, 1996c). A Választott ösztöntendenciák mennyiségi összehasonlítása című, 6. táblázat tájékoztat arról, hogy a „ $\mathrm{k}^{-”}$ ösztöntendencia az átütőerő tekintetében harmadik a sorban, vagyis az ént 
tagadó, az ént és a külvilágot szétromboló destruktív agresszió ugyancsak jellemző a vizsgált személyekre. Az asztmás gyerekek kapcsolati életének sajátossága, hogy az anyában való megkapaszkodás igénye kielégíthetetlen - erre a telített reakciók $\left(\mathrm{m}^{+!}\right)$40\%-nál magasabb volta utal: e kapcsolati frusztráció, a mindenáron való kapaszkodás igénye autoagresszív viselkedésbe csap át.

A vizsgált személyek durva indulataikat felhalmozzák, tehát agresszív késztetéseiket eltitkolják, a külvilág felé - motórium által - történő levezetéssel szemben magukba fojtják és az ellenséges érzületet passzívan önmaguk ellen fordítják. A vizsgálati eredmények szerint az asztmás kisgyerekeknél szervkárosító - acting in jellegű agresszió valószínűsíthető, amelynek végső állomását maga a status asthmaticus jelenti. Mindez megerősíti az a feltételezést, hogy a pszichoszomatikus betegeket (esszenciális hipertóniában, gasztrointesztinális betegségekben szenvedőket) egy sajátos pszichoszomatikus reakciómód jellemzi, amely az agresszió befelé irányuló formájában manifesztálódik (CSÁSZÁR, 1980).

\section{AZ EREDMÉNYEK A PSZICHOANALITIKUS MEGKÖZELÍTÉSEK TÜKRÉBEN}

Szondi Lipót elmélete a pszichodinamikus teóriák sorába tartozik, mely mélylélektani irányzat a sorsanalízis nevet viseli. E fogalom jelentését Szondi a következőképpen határozza meg: „A sorsanalízis = a genetika bevitele a pszichoanalízisbe.” Szondi a sorsanalízis mélypszichológián belüli helyét a freudi és a jungi elmélet közötti területre lokalizálta és a „híd” funkciójával ruházta fel. Míg a pszichoanalízis a személyes tudattalant állította a figyelem fókuszába, addig Jung a kollektív tudattalan szerepét hangsúlyozta. Szondi sorsanalízisében a freudi tudattalant tekinti bázisnak, de annál mélyebbre ás, így jut el a családi tudattalan fogalmához.

A következőkben az asztmás gyerekek Szondi-teszttel végzett személyiségvizsgálata során kapott eredmények és az e betegségre vonatkozó pszichoanalitikus megközelítések közötti azonosságok kerülnek bemutatásra.

Először is a FERENCZI (1982) szervlibidó koncepciójával kapcsolatos hasonlóságra utalok: szerinte az ember lelki müködésének ősi fokát a reflexfolyamat jelenti, amelyre a legmagasabb szintű komplikáltság mellett is visszaeshet. A szomatizáció hátterében ezen „protopszichikus” állapotra való visszaesés található. A regresszió feltételezi, hogy minden libidót visszavonunk a tárgyról és - Ferenczi szavaival élve - valamennyi egoisztikus és libidinózus érdek összesűrüsödik az énben. Viszont számos esetben a külvilágból visszavont libidó egy bizonyos szervben halmozódik fel, amely azon a helyen tüneteket indukál. Az asztmás gyerekeknél a tüdő, illetve a légzőszervrendszer az a kitüntetett szerv, amelyben Ferenczi szerint a libidó felhalmozódik, majd roham formájában levezeti az affektusok és késztetések energiáit.

Ammon (SÜLÉNÉ, 1987) teóriája és a vizsgálati eredményeink között ugyancsak van néhány kapcsolódási pont: archaikus én-betegségek kel kapcsolatos elméletében ő az interperszonális folyamatokra helyezi a hangsúlyt s magát a pszichoszomatikus betegséget patológiás interakciók eredményének tekinti. Ammon a személyiségfej- 
lődés célját a külső és belső világ közötti flexibilis határok kialakításában látja, melynek alapját a kielégítő anya-gyerek szimbiotikus kapcsolat képezi. Csakis ebben a kapcsolatrendszerben tapasztalhatjuk meg önmagunkat és a külvilágot, a kielégítetlen kapcsolati mintázat bizonyos területeken ún. öntapasztalási képtelenséget - azaz az önmagunkról kialakított térképen foltot - eredményez, amelyet Ammon „énben lévő lyuknak” nevez. Az ebben az állapotban lévő személy az öntapasztalási képtelensége miatt nem tud differenciálódni, fejlődni, így diffúz függőségben marad a tárgyaktól. E „lyukak betömését” egy rendkívül meghosszabbodott függőségi kapcsolatforma teszi lehetővé. Az egészséges és asztmás gyerekek ösztönéletét összehasonlítva mindez a teszteredményeken - a kapcsolati élet vektorreakcióin, a $\mathrm{Cm}^{+}$ösztönosztályhoz való tartozáson - keresztül is manifesztté vált: az 5-6 éves asztmás gyerekek ebben az életkorban az elhagyott, de leválásra képtelen gyermek állapotában vannak, ahol ösztönéletüket az anyába való belekapaszkodás irreális szükséglete uralja, míg egészséges társaiknál már megindult az anyáról való leválás folyamata, az ôstárgy elveszítése.

Kutter (CSÁSzÁR, 1989) továbbviszi az ammoni gondolatmenetet és ennek eredményeként az objektum-szubjektum-test viszonyában báziskonfliktust tételez fel. A zavart én- és tárgyviszonylatok révén a pszichoszomatikus betegségben szenvedő egyének nem képesek agressziójukat konstruktív módon levezetni, énjükbe építeni: az asztmás gyerekekre jellemző az agresszió levezetésének lehetetlensége. A vizsgált személyek teszteredményeiben az agresszió megjelenését részletesen feltártam, ez mind a négy ösztönkör vonatkozásában kitüntetett szerepet játszik.

ALEXANDER (1950) a pszichoszomatikus megbetegedéseknek két csoportját különítette el egymástól. Az egyik kategóriába az ún. szimpatogén betegségek tartoznak - ilyen például a hipertónia -, melyeket támadó vagy menekülő reakcióként tart számon; míg a másik csoportot az ún. paraszimpatogén kórformák - például asthma bronchiale - adják, ezeket „halottnak tettetési reflex”-ként írja le. A hipertóniában tartós szimpatikus, míg az asztmában tartós paraszimpatikus túlmúködés jellemző. Alexander szerint az elóbbi esetben az agresszió, az utóbbi esetben pedig a dependenciaigény kerül elfojtásra. E megközelítésből adódóan Alexander az asztmát az anya utáni elfojtott sirásként értelmezi. A 5-6 éves vizsgálati személyekre vonatkozó teszteredmények csak részben támasztották alá e gondolatmenetet: az asztmás kisgyerekek ösztönéletének dinamikáját az anyába való belekapaszkodás szükséglete határozza meg, miközben folyamatosan szoronganak a tárgy elvesztésétól - kapaszkodásuk így görcsössé válik. Alexander teóriájával szemben - a vizsgálati eredmények fényében - azonban nemcsak a dependenciaigény, hanem az agresszív késztetések is elfojtásra kerülnek, mint ahogy az már korábban részletesen bemutatásra került.

A vizsgálatban a NEMIAH és SIFNEOS (1970) által leírt alexitímia - azaz az érzelmek észlelésének, felfogásának zavara - jelenségére hívom fel a figyelmet. A szerzők szerint az alexitímiát mutató személyek sem kimutatni, sem megnevezni nem tudják érzelmeiket, és ezek változatos formáit is csak nehezen tudják megkülönböztetni egymástól. Az 5-6 éves asztmás gyerekekre jellemző a lágy érzelmek elrejtésének igénye, paroxizmális ventilációt használnak az ösztönveszély elhárítására, érzelmeiktől eltávolodva, érzelmi kiürítéssel csökkentik az ösztönveszélyt. 


\section{ÖSSZEGZÉS}

Az 5-6 éves asztmás kisgyerekekkel felvett 10 profilos Szondi-teszt eredményei jelzik, hogy az asthma bronchiale a paroxizmális ösztönkörhöz tartozó betegségforma. Az asztma dinamikáját a rohamok és a közöttük lévő intervallumok adják. A vizsgálati személyek ösztönéletét a hasonló korú egészséges társaikkal összehasonlítva minőségi különbséget tapasztalunk tehát: az egészséges gyerekek kapcsolati életét a tárgyról való leválás jellemzi, amelyet egy új tárgy iránti intenzív vágy kísér. Az asztmás gyerekek szeretet, elfogadás és megkapaszkodás iránti igénye kielégíthetetlen, kapcsolati életükben nem a tárgyról való leválás folyamata a meghatározó, hanem a szorongással kísért görcsös kapaszkodás. Az általam vizsgált személyek az elhagyott, de leválásra képtelen gyerek állapotában vannak ebben az életkorban: a kapcsolati élet frusztrációjából származó agresszív késztetéseiket eltitkolják, a motórium által a külvilág felé végbemenő levezetéssel szemben e késztetéseket magukba fojtják, és az ellenséges érzületet önmaguk ellen fordítják ezáltal valószínűsítve az agresszió szervkárosító, „acting in” irányát.

\section{IRODALOM}

Alexander, A. B. (1950) Psychosomatic medicine. Norton, New York

BerECZKei T. (1997) Szondi, a lélek genetikusa. BUKSZ, 9, 390-398.

Bereczkei T. (1999) Szondi és a modern biológia. In Gyöngyösiné Kiss E. (szerk.) Szondi Lipót. 158-165. Új Mandátum Könyvkiadó, Budapest

Berner, J. (1989) Schicksalanalyse und psychosomatische Medizin. Szondiana, 9, 63.

BRANYiCKy L. (1980) Az asztmáról. Medicina Könyvkiadó, Budapest

CsÁszÁr Gy. (1980) Pszichoszomatikus orvoslás. Medicina Könyvkiadó, Budapest

CsÁszár Gy. (szerk.) (1989) Pszichoszomatika a gyakorlatban. Pszichoteam, Budapest

Cserháti E. (1996) Az asthma bronchiale gyermekkori sajátosságai. Háziorvos Továbbképzö Szemle, 1, 169-171.

Duffy, D., Martin, N. G., Battistutta, D., Hopper, J. L., Mathews, J. D. (1990) Genetics of asthma and hay fever in Australian twins. American Review Respiratory Diseases, 142, 1351-1358.

Engel, G. L. (1977) The need for a new medical model: A challenge for biomedicine. Science, 196, 129-136.

Ferenczi S. (1982) A hisztériás materializáció jelenségei. In Linczényi A. (szerk.) Lelki problémák a pszichoanalízis tükrében. Válogatás Ferenczi Sándor tanulmányaiból. 226-247. Magvetô Kiadó, Budapest

Gershwin, M. E., Halpern, G. M. (ed.) (1994) Bronchial Asthma. Principles of Diagnosis and Treatment. Humana Press, Totowa, New Jersey

GYÖNGYÖSINÉ KIss E. (1999) Szondi Lipót. Új Mandátum Könyvkiadó, Budapest 
GyÖngyösiné Kiss E. (2000) Szerelem és agresszió. A szexualitás és az agresszió értelmezése Szondi sorsanalizisében. XIV. Országos Tudományos Nagygyülés, 2000. május 30.-június 2. Budapest. Absztrakt-kötet, 136.

Hermann I. (1984) Az ember ösi ösztönei. Magvető Könyvkiadó, Budapest

Kopp M. (1999) Pszichogén lelki betegségek és funkciózavarok. Magatartás-orvoslás és pszichoszomatika - áttekintés. http:// www.sote.hu/magtud/kop_pszi.htm

Kulcsár Zs. (1993) Pszichoszomatika. Nemzeti Tankönyvkiadó, Budapest

Kulcsár Zs. (1998) Egészségpszichológia. ELTE Eötvös Kiadó, Budapest

LENFANT C. (ED.) (1992) International Consensus Report on Diagnosis and Treatment of Asthma. European Respiraton Journal, 5, 601-641.

LukÁCS D. (1996) Szondi. Az ösztönprofiltól az elméletig. Animula Könyvkiadó, Budapest

MADARAS I A. (1996) A gyermekkori asthma bronchiale aktuális kérdései. Háziorvos Továbbképzö Szemle, 1, 137-138.

Nemiah, J. C., Sifneos, P. E. (1970) Affect and fantasy in patients with psychosomatic disorders. In Hill, O. W. (ed.) Modern trends in psychosomatic medicine, Vol. 2. 26-34. Butterwoths, London

Noszlopi L. (1989) Sorselemzés és kísérleti ösztöndiagnosztika. Akadémia Kiadó, Budapest

Petz, G. (1953) Triebstrukturanalyse bei Lungentuberkulösen. Szondiana, 1, 134-144.

A pulmonológiai intézmények 1998. évi adatai. Országos Korányi Tbc és Pulmonológiai Intézet, Budapest, 1999.

SonntaG, S. (1983) A betegség mint metafora. Európa Könyvkiadó, Budapest

SÜlÉNÉ KARAKAS Zs. (1987) Az asztmás betegek megértéséhez, pszichodinamikájához és pszichoterápiásan orientált betegvezetéséhez kapcsolódó pszichoszomatikus elméletek. Magyar Pszichiátriai Társaság Pszichoterápiás Szekció, Pszichoterápiás Elméletek és Kutatás Munkacsoport, Budapest

Szondi L. (1931) Beszámoló az V. német gyógypedagógiai kongresszuson, Kölnben elhangzott orvostudományi előadásokról. Magyar Gyógypedagógia, 5-7.

SzONDi, L. (1937) Analysis of Marriages. An attempt at a theory of choice in love. Acta Psychologica Vol. III. no 1. Hága, Martinus Nijhoff

SzOnd, L. (1968) Freiheit und Zwang im Schicksal des Einzelnen. Buchclub Ex Libris, Zürich

SzONDI, L. (1972) Lehrbuch der experimentellen Triebdiagnostik. Band I. Verlag Hans Huber, Bern-Stuttgart-Wien

Szondi L. (1996a) Ember és sors. Három tanulmány. Összeállította és az utószót írta: Gyöngyösiné Kiss Enikő. Kossuth Könyvkiadó, Budapest

SzONDi L. (1996b) A tudattalan nyelvei: szimptóma, szimbólum, választás. Thalassa, 7, 61-82.

SzOndi L. (1996c) Káin, a törvényszegö. Mózes, a törvényalkotó. Gondola '96 Kiadó, Budapest

Szondi L., Moser U., WebB M. (1959) The Szondi Test. J. B. Lippincott 


\section{FATE-ANALYSIS AND PSYCHOSOMATICS: PERSONALITY OF 5-6 YEARS OLD ASTHMATIC CHILDREN REFLECTED BY SZONDI TEST}

\section{HARGITAI, RITA}

For the field of my research, I have chosen the personality examination of asthmatic children at the age of 5 to 6, carried out by Szondi projective test. In the last decade the number of people suffering from asthmatic illnesses has increased. Asthma has become the most frequent chronic illness of childhood; and morbidity, connected with it, is also rising.

Lipot Szondi realised, that our choice of partnership is not directed by chance, as genically related individuals fall in love with each other. Szondi's genuineness lies in finding connection between attitude of choice and psychic qualities: our choices are directed by familiar unconscious; viz. our choices in the areas of love, vocation, illness and death. The realisation of this connection guided him to the experimental diagnostics of drives, namely to the Szondi test.

In the course of the examination I applied 10-profiled Szondi test with 18 children suffering from asthma bronchiale, who have already turned 5 at the beginning of the test, but they haven't turned 6 yet. The analysis of the examinational results takes place on the basis of summarised entries of the child's test. With reference to the result of the Szondi test, asthma bronchiale is an illness belonging to the paroxysmal heredosphere. The dynamics of asthma are given by the attacks and the intervals between them. Comparing the drive life of asthmatic and healthy children at the age of 5 to 6, we can find a qualitative difference: as far as healthy children are concerned, the separation from the object is typical of their connective life, which is accompanied by an intensive desire for a new object. In case of the examined children, the process of separation from the object is not so determining, but the tenacious clinging, which is accompanied by anxiety. So the asthmatic children of this age are in the state of an abandoned child, but they are unable to separate.

Key words: $\quad$ asthma bronchiale, fate-analysis, morbotropism, Szondi-test, paroxysmality 